\title{
Genética molecular: avanços e problemas
}

\author{
Molecular genetics: advances and problems
}

Eloi S. Garcia 1

Claudia Inês Chamas 2

\footnotetext{
1 Vice-Presidência de Pesquisa e Ambiente Fundação Oswaldo Cruz. Av. Brasil 4365, Rio de Janeiro, RJ 21045-900, Brasil. 2 Coordenação de Gestão Tecnológica, Fundação Oswaldo Cruz. Av. Brasil 4365, Rio de Janeiro, RJ 21045-900, Brasil.
}

Abstract This article is an attempt to draw the discussion on molecular genetics in health into the public health domain. Now that the genetic engi neering revolution has arrived, it is important to point out the advances and problems this technology poses for society. It is time for a clear, informed assessment of what we have al ready achieved and may soon achieve using this technology. Clearly, soci ety needs to understand the ethical and practical implications of a technology which can produce mi racle drugs and modern diagnoses and cure virtually every di sease. Important points from sensitive social issues raised by molecular biology and the human genome project are discussed.

Key words Molecular Genetics; Bi otechnology; Public Health; Ethics

Resumo Este artigo traz a discussão sobre genética molecular em saúde ao campo da saúde pública. Com a revolução produzida pela chegada da engenharia genéti ca, é importante discutir al guns dos avanços e problemas desta tecnologia para a sociedade. Está na hora de se fazer uma aval iação clara e bem informada acerca do que já se conseguiu e do que ainda podemos conseguir através desta tecnol ogia. A sociedade precisa compreender as i mplicações éti cas e práti cas de uma tecnologi a capaz de produzir drogas milagrosas, dagnósticos modernos e a cura de todas as doenças. Alguns pontos parti cularmente delicados pertinentes às questões sociais ligadas à biologia molecular e ao projeto genoma humano são discutidos.

Palavras-chave Genética Molecular; Biotecnologia; Saúde Pública; Ética 
A partir de 1972 uma série de descobertas revolucionou o estudo da genética e permitiu o surgimento de uma "nova ciência", a genética molecular ou engenharia genética - um conjunto de técnicas onde um determinado fragmento de DNA (ácido desoxirribonucléico) é isolado e os genes são purificados, examinados e manipulados:

(i) a descoberta de enzimas que tinham a propriedade de clivar (hidrolisar) material genético em locais específicos (seqüências nucleotídicas) dos genes, dividindo a dupla hélice do DNA em pedaços menores - estas enzimas foram chamadas de enzimas de restrição;

(ii) a descoberta de enzimas capazes de unirem fragmentos de DNA (genes) - enzimas de ligação; e

(iii) a descoberta de inúmeros microcromossomos (miniorganismos) - os plasmídios, usados como vetores de fragmentos de DNA. Estava começando uma nova tecnologia baseada na expansão do conhecimento sobre o DNA.

Estas descobertas levaram a tecnologia de clonagem, i.e., a purificação de genes ou cópia deles por reproduzi-los em grande número na bactéria hospedeira. Daí para a tecnologia de DNA recombinante dominar a ciência biológica e biomédica foi um passo. Tornou-se possível o uso de sondas ("probes") genéticas - pedaços de genes ou cópias de DNA complementar - para hibridização. A sonda marcada com traçadores radioativos ou fluorescentes poderia detectar a forma híbrida (complementar) de fragmentos ou regiões específicas do DNA. Esta tecnologia tornou-se o princípio molecular de inúmeras técnicas utilizadas em diagnósticos de doenças genéticas, infecciosas e parasitárias.

A genética molecular pode ser utilizada para fazer com que genes estranhos sejam expressos em bactérias e leveduras ou mesmo em outras células superiores. As indústrias química, farmacêutica e agrária passaram a investir milhares de dólares no desenvolvimento desta tecnologia. Com isto, foram desenvolvidas técnicas capazes de produzir diagnósticos extremamente sensíveis, e corrigir genes com erros inatos, "fabricar" animais transgênicos, etc. Tornou-se possível modificar o genoma e algumas características de um indivíduo na direção planejada. O conhecimento molecular de genes possibilitou a oferta de variados testes na forma de kits, ao contrário dos procedimentos clássicos trabalhosos usados anteriormente em diagnósticos.

Uma outra técnica desenvolvida no mesmo período também por clonagem foi a produção de anticorpos monoclonais, que são utilizados como marcadores genéticos. Juntas, as tecnologias da genética molecular e de hibridoma produziram as ferramentas biológicas necessárias para explorar e conhecer as principais funções celulares em nível molecular e desenvolver métodos sensíveis e específicos de diagnósticos. Nesta área, a biologia começou a ser comercial.

No final dos anos 70 até meados dos anos 80 foram criadas nos EUA várias companhias que se propunham desenvolver comercialmente produtos utilizando estas metodologias. Foi um verdadeiro "boom" na época. Acreditava-se em um novo milagre industrial. Quase tudo na biologia poderia ser produzido desde que fossem conhecidos os genes. Logo depois veio o desencantamento. Nem tudo poderia ser realizado pelo conhecimento gerado pela biologia molecular. Mesmo assim alguns produtos foram consagrados nesta época. Em 1982 a Lilly foi autorizada pelo Food and Drug Administration (FDA) - agência governamental americana responsável pelo registro de medicamentos - para entrar no mercado com a insulina obtida por engenharia genética. Hoje já foram reconhecidos outros produtos: vacina contra hepatite $B$, hormônio de crescimento, ativador de plasminogênio espécie-específico (TPA), alfa-interferon. No entanto, outros produtos não tiveram o mesmo sucesso no mercado.

Com o avanço da engenharia genética e a possibilidade de se conhecer cada gene e sua função nos seres humanos (Projeto Genoma Humano), as ciências biológicas e biomédicas deixaram de ter um papel secundário na evolução das ciências em geral.

O Projeto Genoma Humano está causando uma grande mobilização e esforço de vários países para mapear e investigar o conjunto dos genes humanos. Deve-se lembrar que o complemento total dos cromossomos humanos no núcleo celular contém o equivalente a 3 biIhões de pares de bases. Assumindo, pragmaticamente, que cada gene codifica uma proteína com peso molecular em média de 40.000 daltons, pode-se estimar que um gene corresponde a 1.200 pares de bases. O núcleo da célula humana contém cerca de 2,5 milhões de genes. O DNA contido nas células de um homem, se desenrolado, poderia atingir a lua e voltar. No entanto, um grande número de genes não tem propriedades de codificar proteínas - geralmente são seqüências repetitivas, que não expressam proteínas, ou pseudogenes e introns, pedaços de genes que são eliminados sem função conhecida. Estima-se que o ser humano tenha de 50.000 a 100.000 distintos genes funcio- 
nais contidos em 23 pares de cromossomos. Assim, se tivermos 200 grupos trabalhando, com a tecnologia atual, seriam necessários cerca de 10 a 12 anos para se ter o genoma humano totalmente mapeado. O Projeto Genoma Humano é considerado o mais ambicioso projeto científico realizado neste século. Seu custo é de cerca de 2,5 bilhões de dólares. O biólogo norte-americano Dr. James Dewey Watson ( $\mathrm{n}$. 1928 - ) - um dos descobridores da estrutura de dupla hélice do DNA e prêmio Nobel em 1962 - sugeriu que $3 \%$ deste montante fosse utilizado no estudo dos aspectos éticos, sociais e jurídicos do trabalho. Watson coordenou o Centro Nacional para Pesquisa do Genoma Humano de 1989 a 1992. Em meados de 91, foi anunciado que os National Institutes of Health estariam tentando patentear seqüências de DNA de genes expressos no cérebro humano. Watson foi totalmente contra esta estratégia e, em abril de 92, pediu demissão, ficando como diretor apenas do Laboratório Cold Spring Harbor. Em seu lugar, assumiu Francis Collins, descobridor do gene da fibrose cística.

O mapeamento dos genes permitirá o conhecimento da função de cada um no organismo. A posse de toda a informação codificada no genoma humano nos dá crédito, pelo menos inicial, para compreender os mecanismos do desenvolvimento, da fisiologia e até mesmo do comportamento humano. Ser um biologista nos dias de hoje, na área da bioquímica e da genética molecular, é uma tarefa de entusiasmo e dificuldade. Entusiasmo devido ao avanço no conhecimento que esta tecnologia nos traz e que pode levar a mudanças e a novos desafios sociais e culturais. Dificuldade em função da possibilidade do nascimento de uma nova moral, um novo escrúpulo, uma nova ética científica e tecnológica.

Nos dias de hoje, se há um campo científico em que pesquisadores e sociedade devem estar juntos e fazer uma grande reflexão é a entrada da engenharia genética na área da saúde. Realmente, tem-se diminuído o período de tempo que separa as descobertas nas bancadas dos laboratórios e suas aplicações na saúde pública. Cientistas e população são faces de uma mesma moeda. As recentes tecnologias da biologia molecular e da imunologia, as quais resultaram em métodos de diagnósticos extremamente sensíveis, demoram de 6 a 8 anos para saírem dos laboratórios e serem usados na medicina.

O Projeto Genoma Humano atrai grandes empresas (veja Tabela 1). Os testes para detectar partes falhas do DNA, causadoras de doen- ças como a fibrose cística, representam um mercado no valor de US\$376 milhões ao ano. O método de seqüenciamento rápido de genes desenvolvido por J. Craig Venter, ex-cientista dos National Institutes of Health e atual chefe do The Institute for Genome Research, está levando várias firmas a reavaliarem suas tecnologias.

Tabela 1

Algumas Empresas Envolvidas no Projeto Genoma Humano

Empresas farmacêuticas e firmas de biotecnologia que estão explorando o genoma humano

\begin{tabular}{|c|c|}
\hline Empresa & Estratégia \\
\hline Human Genome Sciences & $\begin{array}{l}\text { Decodificar todos os genes humanos e desenvolve } \\
\text { medicamentos e diagnósticos, em parceria com } \\
\text { outras empresas. }\end{array}$ \\
\hline Smithkline Beecham & $\begin{array}{l}\text { Investiu US } \$ 125 \text { na Human Genome Sciences para } \\
\text { utilizar suas seqüências para criar novos produtos. }\end{array}$ \\
\hline InCyte Pharmaceutical & $\begin{array}{l}\text { Ler DNA de muitos tecidos diferentes para encontrar } \\
\text { genes interessantes. } \\
\text { Vender o acesso aos seus dados. }\end{array}$ \\
\hline Pfizer & $\begin{array}{l}\text { Pagou à InCyte US\$ } 25 \text { milhões para ter acesso ao } \\
\text { banco de dados. }\end{array}$ \\
\hline Upjohn & $\begin{array}{l}\text { Assinou acordo de US\$ } 20 \text { milhões com a InCyte } \\
\text { para obter dados de genes. }\end{array}$ \\
\hline Bristol-M yers Squibb & $\begin{array}{l}\text { Investiu na SEQ e Cadus para desenvolver nova } \\
\text { tecnologia de leitura de genes e seleção de drogas. }\end{array}$ \\
\hline Millennium & $\begin{array}{l}\text { Pesquisar genes específicos que causam a } \\
\text { obesidade, diabetes, asma, ateriosclerose e câncer. }\end{array}$ \\
\hline Hoffmann-LaRoche & $\begin{array}{l}\text { Assinou acordo de US\$ } 70 \text { milhões com a } \\
\text { Millennium. }\end{array}$ \\
\hline Merck & $\begin{array}{l}\text { Pagou à Universidade de Washington para ler } 200 \\
\text { mil fragmentos genéticos. } \\
\text { Divulgar os dados ao público. }\end{array}$ \\
\hline Sequana Therapeutics & $\begin{array}{l}\text { Pesquisar história de famílias e dados da HMO em } \\
\text { busca de genes que causam hipertensão, asma e } \\
\text { obesidade. }\end{array}$ \\
\hline Amgen & $\begin{array}{l}\text { Decodificar genes para encontrar novos alvos de } \\
\text { medicamentos. }\end{array}$ \\
\hline Takeda & $\begin{array}{l}\text { Usar dados da Smithkline e Human Genome } \\
\text { Sciences para desenvolver remédios. }\end{array}$ \\
\hline
\end{tabular}

Fonte: Business Week, 1995. 
A biologia molecular tornou-se um grande "negócio" para a sociedade. Os bons cientistas saíram da "torre de marfim" e junto com profissionais da área de saúde, juristas, filósofos e religiosos, começaram o debate com a sociedade sobre o uso da engenharia genética em seres humanos, o patenteamento da vida e a ética. A sociedade ainda não esqueceu o impacto terrível da experiência nazista, nem as campanhas de esterilização maciça dos alcoólatras, psicóticos, portadores de doenças genéticas realizadas em alguns estados americanos nos anos 20 e 30 . Seria fácil cair no maniqueísmo. Mas, para a ciência, o impacto social de novas técnicas, por exemplo, de diagnóstico pré-natal, erros inatos ou mesmo de reprodução humana assistida, necessitam de uma reflexão profunda da sociedade. Com estes questionamentos é que a bioética entrou seriamente no cenário científico e tecnológico. Seria ético manipular a natureza?

Como vimos, o genoma humano é imenso e possui milhares de genes. O tamanho do DNA humano facilita alterações e combinações genéticas que podem refletir em conhecidas doenças hereditárias. Por longo tempo, essas doenças eram estudadas baseando-se em observações teratogênicas, as malformações congênitas, ou doenças geneticamente transmissíveis, como a conhecida hemofilia, bastante estudada nos descendentes da família real russa.

Após a última guerra os erros inatos começaram a ser investigados pelo refinamento das técnicas citológicas e cariótipos. Os avanços da bioquímica e imunologia permitiram o diagnóstico de várias doenças genéticas relacionadas ao metabolismo - alcaptonúria, cistinúria, hemo-globinopatias, albinismo, etc. A estas doenças acrescentamos outras como anencefalia, espinha bífida, psicoses maníaco-depressivas, doença de Huntington, mal de Alzheimer, síndrome de Down, fibrose cística, mucoviscidose, bem como a detecção dos genes responsáveis pelo câncer de mama vários anos antes do tumor ser detectado por mamografia.

Hoje se conhece cerca de 3.000 doenças relacionadas a "defeitos" genéticos. Estima-se que $1 \%$ dos nascimentos traga de al guma maneira um bebê com deficiência genética, e que $30 \%$ da mortalidade infantil (em países não afetados com doenças endêmicas e má nutrição) estejam relacionados a um erro inato do metabolismo ou a uma malformação congênita - que reflete também alteração metabólica.

Assumindo que 1 gene com defeito causa uma doença genética, há situações em que as modificações levam a condições poligênicas. Por exemplo, fatores ambientais como doenças infecciosas (principalmente as virais) e parasitárias podem causar alterações complexas. Um número alto de pessoas possui condições poligênicas - diabetes dependente de insulina, arteriosclerose, hipertensão, algumas formas de depressão -, onde vários genes se interagem e se combinam com o ambiente e estilo de vida, produzindo a doença.

Como o progresso a engenharia genética permite detecção de cópias ou mesmo fragmentos de genes (hibridização, PCR, RFLP, etc.) havendo possibilidade de se diagnosticar doenças genéticas no recém-nascido ou no feto, ou mesmo em adultos. Quando realizado em pessoas adultas estes dados podem levar ao "aconselhamento" do casal a não ter filhos devido, por exemplo, à probabilidade de ter genes de alto risco. Um outro ponto a ser considerado é a conseqüência da doença para o recém-nascido ou feto, quando não há terapia. A sociedade não deve subestimar este problema.

As conseqüências legais e morais de uma expansão de diagnósticos genéticos são ameaçadoras. Por exemplo, o que fariam os pais de uma criança nascida com erro inato de metabolismo, se soubesse que a doença poderia ser diagnosticada no feto, ou mesmo antes da concepção do bebê? Um outro problema, a impressão "genética" (DNA fingerprint) de um indivíduo - tecnologia já utilizada hoje para identificação de paternidade e que, futuramente, poderá ser utilizada para apoio às autoridades de imigração, identificar "possíveis" alterações individuais ou "potenciais" modificações de personalidade, ou mesmo fatores de risco para determinadas doenças hereditárias - e produzir seres humanos de primeira e segunda classe. O que fariam a medicina preventiva, as companhias de seguro, as indústrias na seleção de seus empregados, o noivo na escoIha da companheira, etc? A sociedade precisa saber disto.

Vamos aprofundar um pouco mais estes pontos. Um feto com alguns meses de desenvolvimento que apresentasse, por diagnóstico genético, uma doença hereditária. Seria recomendável um aborto? Esta tentação de eugenia nos leva a esquecer a essencialidade humanitária, a sensibilidade das pessoas, a ética pessoal. A sociedade precisa discutir profundamente esta questão.

A engenharia genética poderia ainda influenciar a medicina no controle da reprodução. Por exemplo, poderia modificar embriões humanos por técnicas transgênicas. Isto quer dizer, manipulação de genes, eliminação de genes "ruins" e inserção de genes "bons" (terapia gênica). Certas doenças poderão ser tratadas 
por reposição do gene defeituoso. Seria a versão moderna do bebê de proveta ou da reprodução assistida. É bem verdade que reprodução assistida, principalmente, inseminação artificial, fertilização "in vitro", implante de embrião, já vem sendo usada pela medicina veterinária por vários anos. A medicina humana começou a usar estas tecnologias mais recentemente. Neste cenário podemos pensar que uma criança poderá ser "gerada" totalmente fora do organismo da mãe, como as plantas cultivadas na ausência de solo, no Epcot Center (EUA).

Genes foram inseridos em camundongos, coelhos, porcos e ovelhas. Cerca de dez anos após a descoberta da transgênese foram produzidas mais de 1.000 cepas de camundongos e mais de dez tipos de porcos geneticamente alterados. Hoje já são geradas ovelhas que produzem leite contendo fator 9 , que pode ser extraído e utilizado como medicamento para hemofilia. Também foi criada um tipo de ovelha que produz leite contendo TPA em quantidade suficiente para suprir a demanda mundial da droga.

O patenteamento da vida é outra questão bastante complexa. Em 1972, a microbiologista Ananda Chakrabarty, da Universidade de Illinois, desenvolveu um microorganismo engenheirado não-recombinante capaz de degradar componentes do petróleo bruto. Em 1980, a Suprema Corte Americana concedeu a patente a este microorganismo, constituindo o primeiro ser vivo patenteado nos EUA. O caso tornou-se jurisprudência para o Escritório Americano de Patentes. Desde então, os pedidos de patente relacionados a seres vivos parecem não ter limites. Em 12 de abril de 1988 foi concedida à Universi dade de Harvard a patente U.S. 4.736.866, para um rato transgênico, que continha um gene causador de câncer.

O problema ético é sério. Os conhecimentos sobre a genética humana e animal podem ser explorados economicamente por empresas? A tendência internacional é que prevaleça as razões econômicas. Acreditamos que em breve as legislações de propriedade industrial dos países em desenvolvimento estarão adaptadas aos novos tempos e à globalização dos mercados, de acordo com a lógica neoliberal.

A sociedade precisa refletir e decidir como ela quer e deve utilizar os conhecimentos gerados pela engenharia genética. Não basta ter uma vida saudável e maior expectativa de vida. É necessária uma vida ética e necessariamente mais feliz.

Para finalizar, historicamente sabemos que quando Darwin publicou há cerca de 130 anos a obra "A Origem das Espécies", a sociedade reagiu às idéias levantadas pelo cientista sobre "seleção natural". Este conceito mudou os rumos da biologia nos últimos 100 anos. Hoje a nossa sociedade deve discutir se a manipulação da natureza pelas técnicas de biologia molecular pode levar a uma "seleção induzida/ artificial". Talvez, nos próximos 100 anos tenhamos uma compreensão melhor do que significa a biologia molecular e a engenharia genética para a humanidade. 